\title{
Peningkatan Pengetahuan dan Sikap Ibu tentang MP- ASI (Makanan Pendamping Air Susu Ibu) di Desa Hendrosari Menganti Gresik
}

\section{Increased Knowledge and Attitude of Mothers about Complementary Food for Mother's Milk in Hendrosari Village, Menganti Gresik}

\author{
${ }^{1}$ Yuanita Syaiful, ${ }^{1}$ Lilis Fatmawati, ${ }^{2}$ Siti Aminah \\ ${ }^{1}$ Program Studi Ilmu Keperawatan Fakultas Ilmu Kesehatan Universitas Gresik \\ ${ }^{2}$ Mahasiswa PSIK FIK Universitas Gresik
}

Korespondensi : Y. Syaiful, ntsyaiful271@gmail.com

Naskah Diterima: 6 Oktober 2019. Disetujui: 19 Februari 2020. Disetujui Publikasi: 6 Maret 2020

\begin{abstract}
ASI complementary foods (MP-ASI) are foods or drinks that contain nutrients, given to infants and children to meet their nutritional needs. MP-ASI is given together with ASI from the age of 6 months to 24 months. As the baby gets older, after the baby is 6 months old, it starts to be introduced with complementary foods to meet its nutritional needs. Too early to give MP-ASI will cause the fulfillment of the baby's milk needs is reduced. MP-ASI less than 6 months of age can increase the risk of diarrhea, dehydration, decreased milk production and allergies. Providing education in the form of health education about the provision of MP-ASI for infants aged 0-6 months is an educational strategy for mothers to apply the knowledge they have acquired and change the wrong attitude independently. The purpose of this activity is to increase knowledge and attitudes about MP-ASI for mothers in the village of Hendrosari Menganti Gresik. The activity was carried out in full involvement of the mother in accordance with the target, starting from educational activities namely health counseling about MP-ASI to mothers who gave MP-ASI to infants younger than 6 months, demonstrating the preparation of MP-ASI with correct consistency and small group discussions. The results of this activity showed an increase in knowledge and attitudes towards mothers about MP-ASI with established indicators of success.
\end{abstract}

Keywords: Health education, knowledge, attitude, MP-ASI.

\begin{abstract}
Abstrak. Makanan pendamping ASI (MP-ASI) adalah makanan atau minuman yang mengandung gizi, diberikan pada bayi dan anak untuk memenuhi kebutuhan gizinya. MP-ASI diberikan bersamaan dengan ASI mulai usia 6 bulan hingga 24 bulan. Seiring bertambahnya usia bayi, setelah bayi berusia 6 bulan, mulai diperkenalkan dengan makanan pendamping untuk memenuhi kebutuhan gizinya. Terlalu dini memberikan MP-ASI akan menyebabkan pemenuhan kebutuhan ASI bayi berkurang. MP-ASI kurang dari usia 6 bulan dapat menimbulakn risiko diare, dehidrasi, produksi ASI menurun dan alergi. Pemberian edukasi dalam bentuk pendidikan kesehatan tentang pemberian MP-ASI pada bayi usia 0-6 bulan merupakan strategi pendidikan kepada para ibu untuk mengaplikasikan pengetahuan yang telah didapat dan merubah sikap yang salah secara mandiri. Tujuan kegiatan ini adalah meningkatkan pengetahuan dan sikap tentang MP-ASI pada ibu di Desa Hendrosari Menganti Gresik. Kegiatan dilaksanakan dengan melibatkan secara penuh ibu sesuai sasaran, mulai dari kegiatan edukasi yakni penyuluhan kesehatan tentang MP-ASI pada ibu yang memberikan MPASI pada bayi usia kurang dari 6 bulan, peragaan penyiapan MP-ASI dengan konsistensi yang benar dan small group discussion. Hasil kegiatan menunjukkan terjadi peningkatan
\end{abstract}


pengetahuan dan sikap pada ibu tentang MP-ASI dengan indikator keberhasilan yang ditetapkan.

Kata kunci : Pendidikan kesehatan, pengetahuan, sikap, MP-ASI.

\section{Pendahuluan}

MP-ASI merupakan makanan yang diberikan ke bayi selain ASI. Sebagai pendamping ASI juga berguna untuk menunjang pertumbuhan pada bayi. MP-ASI adalah makanan yang diberikan kepada bayi guna memenuhi kebutuhan bayi atau anak dalam melengkapi ASI dan biasanya diberikan pada bayi usia 6-24 bulan atau lebih (Krisnatutu, 2008). MP-ASI yang baik adalah kaya energi, protein, mikronutrien, mudah dimakan anak, berasal dari bahan makanan lokal dan terjangkau, serta mudah disiapkan. Banyaknya kasus kurang gizi di dunia, terutama kasus kurang protein, zat besi dan vitamin A telah mendorong WHO sebagai badan kesehatan dunia untuk memperbarui beberapa prinsip penting di tahun 2010 untuk panduan pemberian makan bagi bayi dan anak (Aryani, 2010).

Bayi harus diberi ASI eksklusif baru dilanjut dengan MP-ASI. WHO mengeluarkan standar agar setiap ibu memberikan ASI eksklusif kepada bayi sejak lahir sampai usia 6 bulan. Ini artinya pemberian MP-ASI mulai dilakukan setelah bayi usia 6 bulan. Masih banyak ibu yang memberikan MP-ASI kepada bayi usia kurang dari 6 bulan. Padahal pemberian MP-ASI terlalu dini mempunyai dampak risiko kontaminasi yang sangat tinggi, yaitu terjadinya gastroenteritis yang sangat berbahaya bagi bayi dan dapat mengurangi produksi ASI lantaran bayi jarang menyusui.

Berdasarkan hasil Survey Sosial Ekonomi Nasional (SUSENAS) (2010) terdapat banyak ibu yang memberikan MP-ASI kepada bayi usia 2-3 bulan, seperti bubur, nasi, dan pisang. Sedangkan 69\% adalah pada bayi usia 4-5 bulan (Depkes RI, 2010). Data dari Dinas Kesehatan Jawa Timur menyebutkan selama tahun 2010 dari total 11.010 bayi yang diperiksa terdapat 10.071 bayi yang sudah diberi MP-ASI sebelum usia 6 bulan (Dinkes Jatim, 2010).

Posyandu Desa Hendrosari Kecamatan Menganti Kabupaten Gresik adalah salah satu kegiatan kesehatan dasar yang diselenggarakan oleh atau untuk masyarakat yang dibimbing oleh petugas kesehatan terkait. Adapun kegiatan Posyandu ini secara rutin dilaksanakan setiap satu bulan sekali yaitu pada minggu ke-2 yang diikuti oleh balita sekitar kurang lebih 60 - 65 balita. Adapun kegiatan yang dilakukan di Posyandu antara lain penimbangan secara rutin untuk memantau pertumbuhan balita, pemberian MP-ASI, pemberian vitamin A, melakukan pelayanan imunisasi dan tanda-tanda tumbuh layu dan lain-lain (screening tumbuh kembang).

Posyandu wilayah Desa Hendrosari Kecamatan Menganti didapatkan data masih banyak ibu yang memberikan MP-ASI pada bayi yang usia kurang dari 6 bulan yaitu sebanyak 60\% dari 33 bayi (Dinas Kesehatan Kabupaten Gresik, 2018). Hasil studi pendahuluan yang dilaksanakan di posyandu Desa Hendrosari Kecamatan Menganti Kabupaten Gresik pada tanggal 17 Mei 2019 dari 33 ibu terdapat $10 \mathrm{ibu}$ yang mempunyai pengetahuan kurang tentang pemberian MP-ASI dan 20 ibu yang dinilai mempunyai sikap yang kurang tentang pemberian MP-ASI dini pada bayinya Upaya yang dilakukan di posyandu untuk meningkatkan pengetahuan yaitu dengan memberikan pendidikan kesehatan tentang MP-ASI. Pendidikan kesehatan merupakan upaya yang direncanakan untuk mempengaruhi orang lain baik individu, kelompok, atau masyarakat sehingga melakukan apa yang diharapkan (Notoatmodjo, 2007).

Pendidikan kesehatan ibu ditujukan pada ibu yang memberikan MP-ASI pada bayi usia kurang dari 6 bulan, demi terciptanya ibu yang mendukung perubahan sikap menjadi lebih baik dengan cara tidak memberikan MP-ASI sebelum usia 6 bulan. Pendidikan kesehatan adalah cara yang efektif untuk meningkatkan 
pengetahuan dan sikap pada kelompok sasaran yang dituju. Hal tersebut sudah terbukti melalui penelitian bahwa masalah gizi pada bayi dan anak disebabkan kebiasaan pemberian ASI dan MP-ASI yang tidak tepat.

Penelitian Widyastuti (2011) menunjukkan bahwa ada hubungan antara tingkat pengetahuan dalam pemberian MP-ASI terlalu dini yang menyebabkan gangguan pencernaan pada bayi seperti diare, konstipasi, muntah, dan alergi. Pemberian MP-ASI kurang dari 6 bulan mempengaruhi tingkat kecerdasan pada anak (Nadesul, 2011). Kurangya pengetahuan ibu tentang makanan yang tepat pada bayi usia kurang dari 6 bulan dapat menyebabkan terjadi masalah gizi pada bayi (Tirtawinata, 2006). Pendidikan kesehatan berupa penyuluhan tentang MP-ASI menjadi salah satu kegiatan yang bisa dipilih untuk meningkatkan pengetahuan dan sikap ibu tentang tujuan, macam-macam, kapan MP-ASI diberikan, manfaat, dan dampak pemberian MP-ASI terlalu dini. Penyuluhan dilakukan pada ibu yang memberikan MP-ASI pada bayi usia kurang dari 6 bulan.

Tujuan pengabdian ini yaitu untuk meningkatkan pengetahuan dan sikap ibu tentang MP-ASI pada ibu yang memberikan MP-ASI pada bayi usia kurang dari 6 bulan di Desa Hendrosari Menganti Gresik. Hasil dari pengabdian ini diharapkan dapat memberikan pengetahuan dan ibu lebih sadar untuk bersikap dan berperilaku sesuai dengan pedoman pemberian MP-ASI pada bayi sehingga dapat mencegah terjadinya obesitas dan menurunkan risiko terjadinya alergi pada bayi.

\section{Metode Pelaksanaan}

Tempat dan Waktu. Kegiatan pengabdian ini dilaksanakan di Balai Desa Desa Hendrosari Menganti Gresik pada hari Senin - Selasa Tanggal 10-11 Juni 2019, pukul 08.00-12.00 WIB.

Khalayak Sasaran. Khalayak sasaran adalah ibu yang memberikan MP-ASI pada bayi usia kurang dari 6 bulan sebanyak 30 peserta. Pemilihan peserta berdasarkan usulan dan diskusi dengan kader kesehatan dan bidan desa yang ada di wilayah posyandu Desa Hendrosari.

Metode kegiatan. Kegiatan ini dirancang menggunakan metode edukasi berupa penyuluhan kesehatan, peragaan penyiapan MP-ASI dengan konsistensi yang benar, dan small group discussion, meliputi :

A. Edukasi tentang MP-ASI

Edukasi tentang MP-ASI diberikan melalui tahapan pada umumnya yaitu pembukaan, pelaksanaan, evaluasi dan terminasi. Metode yang digunakan adalah ceramah (Gambar 1). Materi diberikan menggunakan PPT alat bantu berupa LCD dan proyektor, serta pembagian leaflet tentang MP-ASI. Edukasi ini dilakukan di balai desa Desa Hendrosari saat ada kegiatan posyandu balita. Materi yang diberikan kepada peserta meliputi: Pengertian MP-ASI, Jenis MPASI, MP-ASI yang baik, waktu yang tepat memberikan MP-ASI, manfaat dan tujuan pemberian MP-ASI, dampak pemberian MP-ASI dini. Untuk evaluasi kegiatan dilakukan pre dan post test tentang MP-ASI dengan menggunakan kuesioner yang dibagikan kepada peserta utuk mengetahui tingkat pengetahuan dan sikap awal dan akhir khalayak sasaran tentang MP-ASI pada ibu (Kudsiah, dkk., 2018).

B. Peragaan penyiapan MP-ASI dengan konsistensi yang benar

Setelah diberikan materi tentang MP-ASI, tim pengabdian melakukan peragaan atau simulasi penyiapan MP-ASI untuk bayi. Tim memberikan contoh prakik pembuatan MP-ASI pada bayi dengan konsistensi yang benar. Kemudian hasil MP-ASI tersebut diberikan kepada bayi (Gambar 2).

C. Small Group Discussion (SGD)

Setelah dilakukan penyampaian materi dan praktik pembuatan MP-ASI, tim pengabdian melakukan kegiatan SGD kepada peserta, memberikan kesempatan 


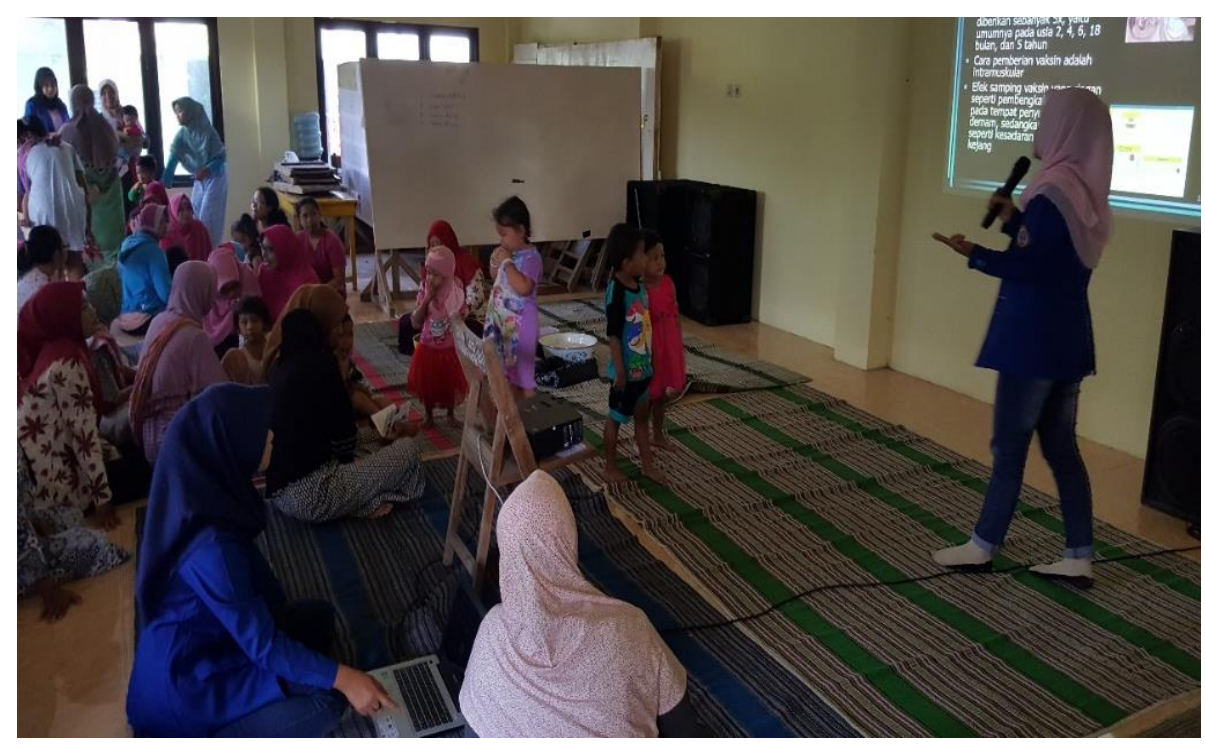

Gambar 1. Kegiatan edukasi tentang MP-ASI

D. Peragaan penyiapan MP-ASI dengan konsistensi yang benar

Setelah diberikan materi tentang MP-ASI, tim pengabdian melakukan peragaan atau simulasi penyiapan MP-ASI untuk bayi. Tim memberikan contoh prakik pembuatan MP-ASI pada bayi dengan konsistensi yang benar. Kemudian hasil MPASI tersebut diberikan kepada bayi.

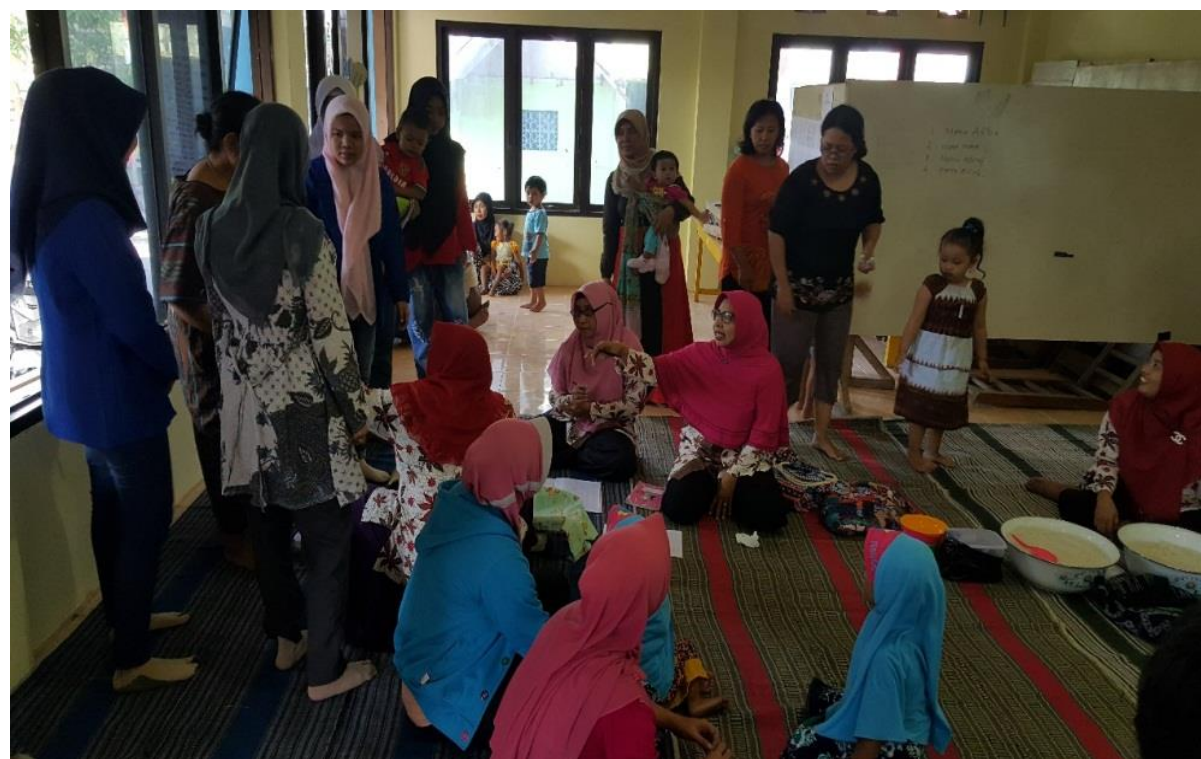

Gambar 2. Peragaan penyiapan MP-ASI dengan konsistensi yang benar

kepada peserta untuk bertanya apabila tidak dimengerti terkait MP-ASI dan peragaan yang sudah dilakukan.

Indikator Keberhasilan. Indikator keberhasilan kegiatan ini adalah

a. Edukasi tentang MP-ASI. Edukasi dikatakan berhasil apabila lebih dari 50\% peserta berada dalam tingkat pengetahuan yang baik (pengetahuan meningkat) dan memiliki sikap positif artinya ibu tidak memberikan MP-ASI kepada bayi kurang dari enam bulan.

b. Peragaan penyiapan MP-ASI dengan konsistensi yang benar. Kegiatan ini dikatakan berhasil apabila lebih dari 50\% peserta mampu mempraktekkan MPASI sesuai dengan usia bayi diikuti dengan konsistensi yang benar. 
c. Small Group Discussion (SGD). Kegiatan SGD dikatakan berhasil apabila lebih dari $50 \%$ peserta aktif baik dalam bertanya, diskusi, ataupun kehadiran dalam kegiatan mulai dari awal sampai akhir.

Metode Evaluasi. Metode evaluasi pada kegiatan ini yaitu mengukur pengetahuan dan sikap peserta menggunakan kuesioner pengetahuan dan sikap pada saat pre dan post. Setelah itu hasil kuesioner dianalisis dengan manajemen data yang terstandar meliputi: editing, coding, scoring, analisa data dan tabulating. Data diolah menggunakan perangkat lunak SPSS dan disajikan dalam bentuk tabel frekuensi. Evaluasi peragaan MP-ASI yaitu menilai peserta mampu mempraktekkan MP-ASI dengan konsistensi yang benar. Sedangkan untuk menilai evaluasi SGD yaitu peserta mampu memahami tentang MP-ASI yang benar dengan kriteria aktif dalam diskusi.

\section{A. Edukasi MP-ASI}

\section{Hasil dan Pembahasan}

Pengetahuan dan sikap tentang MP-ASI pada ibu mengalami peningkatan pengetahuan dan sikap (Tabel 2). Dijelaskan bahwa pengetahuan ibu sebelum dilakukan pendidikan kesehatan sebagian besar yaitu 21 ibu $(70 \%)$ berpengetahuan baik, sebagian kecil yaitu 8 ibu (27\%) berpengetahuan cukup dan sebagian kecil yaitu 1 ibu (3.3\%) berpengetahuan kurang, sedangkan pengetahuan Ibu sesudah dilakukan pendidikan kesehatan tentang MP-ASI mengalami peningkatan yaitu seluruhnya yaitu $30 \mathrm{ibu}$ (100\%) berpengetahuan baik. Hasil tersebut sesuai dengan target kegiatan pengabdian yaitu meningkatkan pengetahuan ibu dalam kategori baik lebih dari 50\%.

Berdasarkan tabel 3 dapat dijelaskan bahwa hasil menunjukkan sikap ibu sebelum dilakukan pendidikan kesehatan sebagian besar 17 ibu (57\%) bersikap positif dan hampir setengah 13 ibu (43.33\%) bersikap negatif (memberikan MP-ASI kurang dari enam bulan), sikap ibu meningkatan setelah diberikan pendidikan kesehatan tentang MP-ASI yaitu sebesar $22 \mathrm{ibu}(73,3 \%)$ artinya ibu bersikap positif untuk tidak memberikan MP-ASI ke bayi sebelum usia enam bulan.

Pengetahuan MP-ASI adalah Pengetahuan tentang makanan tambahan yang diberikan pada bayi berusia 6 bulan sampai bayi berusia 24 bulan. Peranan MPASI sama sekali bukan untuk menggantikan ASI, melainkan hanya untuk melengkapi ASI (Yenrina, 2008). Pengetahuan tentang MP-ASI seorang ibu juga besar pengaruhnya bagi perubahan sikap didalam pemilihan bahan makanan yang selanjutnya berpengaruh pada tumbuh kembang dan gizi anak yang bersangkutan. Sikap merupakan reaksi tertutup dan belum merupakan suatu tindakan atau aktivitas akan tetapi merupakan predisposisi tindakan suatu perilaku. Umumnya alasan ibu memberikan makanan pendamping ASI yang tidak tepat sesuai usia bayi adalah karena bayi sering menangis sehingga ibu menganggap bahwa bayinya masih lapar, ibu merasa dengan memberikan makanan tambahan bayi akan sehat serta bayi cepat tumbuh besar.

\section{B. Peragaan penyiapan MP-ASI dengan konsistensi yang benar}

Hasil kegiatan menunjukkan bahwa $75 \%$ ibu bisa dan mampu mempraktekkan pembuatan MP-ASI sesuai usia bayi dengan konsistensi yang benar. Kategori waktu pemberian MP-ASI yang sesuai adalah usia 6 bulan 29 hari dan kategori waktu pemberian MP-ASI tidak sesuai adalah usia $<6$ atau $>6$ bulan (Marimbi, 2010). Anak yang mendapatkan MP-ASI yang tidak sesuai dengan waktu memulai pemberian MP-ASI memiliki risiko 2,8 kali untuk menjadi stunting ( $z$ score <-2). Hal ini berarti waktu memulai pemberian MP-ASI berhubungan secara signifi kan dengan kejadian stunting. Setelah usia 6 bulan, ASI hanya memenuhi sekitar $60-70 \%$ kebutuhan gizi bayi. Sehingga bayi mulai membutuhkan Makanan Pendamping ASI (MP ASI). Jumlah/porsi MP-ASI hendaknya diberikan secara 
bertahap, berangsur mulai dari satu sendok hingga bertambah sesuai porsi kebutuhan bayi sesuai dengan usianya (WHO, 2006).

Kebutuhan energi dari makanan pada anak di negara berkembang adalah sekitar $200 \mathrm{kkal}$ per hari untuk bayi usia 6-8 bulan, $300 \mathrm{kkal}$ per hari untuk bayi usia 9-11 bulan dan $550 \mathrm{kkal}$ per hari untuk usia 12-23 bulan. Rekomendasi WHO dalam praktik pemberian Makanan Pendamping ASI menyebutkan bahwa jumlah/porsi makanan anak disesuaikan dengan usia. Ketika anak berusia 6 bulan diberikan makanan tambahan mulai dengan dua sampai tiga sendok makan dengan pengenalan rasa dan secara perlahan ditingkatkan jumlahnya, dari usia 69 bulan ditingkatkan secara perlahan sampai setengah mangkuk berukuran 250 ml. Usia 9-12 bulan diberikan setengah sampai tiga perempat mangkuk berukuran $250 \mathrm{ml}$, kemudian dari usia 12-24 bulan diberikan tiga perempat sampai satu mangkuk ukuran $250 \mathrm{ml}$ (WHO, 2006).

WHO (2006) menyatakan bahwa tekstur (kekentalan/konsistensi) makanan MP-ASI diberikan sesuai dengan usia anak dan secara bertahap untuk perkembangan anak yang optimal. Jika konsistensi makanan yang diberikan tidak sesuai dengan usia anak, kemungkinan mengkonsumsi makanan membutuhkan lebih banyak waktu untuk mengunyah menjadi partikel yang lebih kecil untuk ditelan, akibatnya anak akan makan dalam jumlah yang lebih sedikit (lama mengunyah) sehingga asupan makanannya akan kurang. Pada usia 12 bulan anak sudah dapat mengkonsumsi makanan padat atau makanan keluarga, meskipun masih banyak ditawarkan makanan semi padat (memudahkan untuk menelan). Menunda memperkenalkan makanan padat pada anak pada usia lebih dari 10 bulan meningkatkan risiko kesulitan makan nantinya.

Makanan Pendamping ASI anak usia 6 bulan berupa bubur kental sebagai tahap pengenalan awal MP-ASI kurang lebih selama 2 minggu, kemudian dari usia 6 sampai 9 bulan diberikan bubur kental/makanan keluarga yang dilumatkan, selanjutnya dari usia 9 sampai 12 bulan diberikan makanan keluarga yang dicincang atau makanan dengan potongan kecil yang dapat dipegang/di iris-iris dan dari usia 12-24 bulan diberikan makanan yang diiris-iris atau makanan keluarga (WHO, 2006).

\section{Small Group Discussion (SGD)}

Kegiatan SGD menunjukkan 80\% ibu aktif mengikuti kegiatan mulai dari awal sampai akhir, ibu kooperatif saat berdiskusi tentang MP-ASI, ibu bertanya apabila ada yang tidak dimengerti. Pendidikan kesehatan merupakan upaya meningkatkan serta mengubah pengetahuan dan sikap tentang MP-ASI kearah yang lebih baik. Faktor yang mendukung meliputi sarana, peran kader posyandu, media pendidikan kesehatan, materi yang disampaikan, komunikasi dan penyampaian materi. Adanya sarana yang mendukung dapat menarik perhatian responden untuk memperhatikan sehingga responden menjadi kooperatif terhadap pendidikan kesehatan yang diberikan. Pemberian informasi melalui metode pendidikan kesehatan mengutamakan kualitas dari materi, penguasaan komunikasi dan responden sehingga dalam memberikan informasi akan lebih efektif. Ibu-ibu yang diberikan pendidikan kesehatan dapat meningkatkan pengetahuan dan sikap dalam MP-ASI.

\section{Keberhasilan kegaitan}

Edukasi tentang MP-ASI dilaksanakan di balai desa Desa Hendrosari Menganti Gresik saat kegiatan posyandu, dihadiri oleh 30 peserta dan didampingi oleh bidan desa, serta kader kesehatan. Acara dilaksanakan selama 2 hari yakni hari pertama dilakukan pre test dengan kuesioner, dilanjut dengan pemberian edukasi MP-ASI (pembukaan, pelaksanaan, evaluasi, dan terminasi) oleh tim pengabdian yang meliputi: pengertian MP-ASI, Jenis MP-ASI, MP-ASI yang baik, 
waktu yang tepat memberikan MP-ASI, manfaat dan tujuan pemberian MP-ASI, dampak pemberian MP-ASI dini, serta peragaan penyiapan MP-ASI dengan konsistensi yang benar berdasarkan standart dari WHO. Diawali dengan memilih MP-ASI sesuai dengan usia bayi dan cara pengolahan dengan konsistensi yang benar. Setelah diberi contoh peragaan pembuatan MP-ASI, peserta diminta untuk mempraktikan yang sudah dicontohkan. Edukasi dibuat semenarik mungkin agar peserta tidak merasa bosan. Tim pengabdian semaksimal mungkin membuat slide PPT dengan bahasa yang mudah difahami oleh peserta, fasilitator berusaha menjelaskan dengan bahasa yang sederhana agar mudah diterima dan dimengerti oleh peserta. Pada hari ke dua dilakukan small group discussion (SGD), dan evaluasi berupa post test diakhir kegiatan. Tim pengabdian memberikan kesempatan kepada khalayak sasaran untuk bertanya dan melakukan diskusi. Kegiatan SGD dilakukan setelah semua materi dan peragaan disampaikan dengan demikian diharapkan khalayak sasaran bisa memahami secara penuh dengan baik. Untuk mengetahui apakah edukasi yang diberikan efektif apa tidak, maka dilakukan pre test dan post test dengan kuesioner. Kuesioner sebelumnya disusun dengan sebaik mungkin dengan pengujian validitas dan reliabilitas sehingga bisa digunakan untuk menilai tingkat pengetahuan dan sikap tentang MP-ASI pada khalayak sasaran. Khalayak sasaran sangat antusias mengikuti kegiatan dari hari pertama sampai akhir. Pada sesi SGD tim pengabdian membagi 2 sesi untuk bertanya, tim pengabdian berusaha menjawab pertanyaan dengan jawaban yang mudah difahami dan dimengerti dengan memberikan contoh nyata.

Hasil yang telah dilakukan pada 30 responden menunjukkan bahwa pengetahuan ibu sebelum dilakukan pendidikan kesehatan tentang MP-ASI pada bayi usia 0-6 bulan sebagian besar berpengetahuan baik yaitu 21 orang $(70 \%)$, akan tetapi dari penilaian pengetahuan dari pertanyaan no 4 dan 6 hampir setengah dari responden kurang memahami maksud dari pertanyaan tersebut, hal ini disebabkan tingkat pemahaman yang terbatas dan sebagian dari responden tersebut tinggal serumah dengan mertua atau orang tuanya sehingga mereka dapat terpengaruh dengan keputusan mertua atau orang tuanya. Responden tergolong pengetahuan cukup yaitu hampir setengah responden 8 orang $(27 \%)$, pengetahuan responden sesudah mendapatkan pendidikan kesehatan tentang MP-ASI pada bayi usia 0-6 bulan seluruh responden berpengetahuan baik 30 responden $(100 \%)$. Hasil pengabdian menunjukkan bahwa terjadi peningkatan pengetahuan ibu tentang pemberian MP-ASI pada bayi usia 0-6 bulan dipengaruhi umur ibu yang masih produktif. Pengetahuan juga dipengaruhi oleh tingkat pendidikan responden sebagian besar SMA sebesar 19 orang (63.3\%), semakin tinggi pendidikan seseorang makin mudah menerima informasi. Pekerjaan merupakan salah satu yang mempengaruhi pengetahuan sebagian besar responden sebagai pekerja swasta, hal ini menjadikan semakin banyak informasi yang didapat dari luar karena berinteraksi dengan banyak teman sehingga saling tukar pengalaman. Pendidikan kesehatan adalah segala upaya yang direncanakan untuk mempengaruhi orang lain, baik individu, kelompok, atau masyarakat, sehingga mereka melakukan apa diharapkan oleh pelaku pendidikan atau promosi kesehatan (Notoatmodjo, 2007).

Dari hasil yang telah dilakukan pada 30 responden sikap ibu sebelum dilakukan pendidikan kesehatan sebagian besar responden 17 orang $(57 \%)$ bersikap positif dan setengah responden 13 orang $(43.33 \%)$ bersikap negatif. Namun sebelum dilakukan pendidikan kesehatan pada pertanyaan no 6 ada 2 responden menjawab sangat setuju, pertanyaan no 7 ada 1 responden yang menjawab sangat setuju dan pertanyaan no 10 juga ada 1 responden yang menjawab sangat setuju, hal ini disebabkan para ibu tersebut kurang memahami maksud dari pertanyaan tersebut. Sedangkan sikap ibu sesudah dilakukan 
pendidikan kesehatan menjadi meningkat yaitu sebagian besar responden 22 orang $(73.3 \%)$ bersikap positif dan setengahnya 8 orang $(26 \%)$ bersikap negatif. Dapat dijelaskan bahwa yang mempengaruhi sikap ibu menjadi meningkat dipengaruhi pendidikan, menunjukkan dari 30 responden sebagian besar 19 orang $(63.3 \%)$ berpendidikan SMA. Semakin tinggi pendidikan seseorang makin mudah menerima informasi, sehingga lebih mudah untuk merubah sikap seseorang. Dari 30 responden sebagian besar responden yang tinggal dengan keluarga inti sebanyak 19 orang (63.3\%) sehingga mereka lebih berfikir mandiri untuk memenuhi kebutuhan keluarganya tanpa ada campur tangan dari luar (orang tua / mertua). Untuk mempersiapkan seorang ibu yang akan diberikan pendidikan kesehatan haruslah diberikan pengetahuan dalam berbagai bentuk, dengan metode ceramah responden akan lebih tahu. Sekali kepercayaan itu terbentuk maka akan menjadi dasar sikap seseorang mengenai apa yang diharapkan objek tertentu.

Meningkatnya sikap responden tersebut menjadikan dasar meningkatnya sikap responden karena sikap merupakan perwujudan dari pengetahuan yang diterima oleh responden dan responden menjadi lebih memahami bahwa pemberian MP-ASI pada bayi usia 0-6 bulan itu sangat penting. Hal ini yang membuat responden bersikap positif karena sebagian besar mereka sudah mendapatkan informasi tentang kesehatan baik dari media massa, elektronika dan yang lainny. Bila dilihat dari hasil sebelumnya sikap ibu dapat dirubah melalui pemberian pendidikan dan edukasi tentang kesehatan yang baik dan benar.

Khalayak sasaran yang mengikuti edukasi ini adalah ibu yang memberikan MP-ASI pada bayi usia kurang dari 6 bulan didampingi dengan bidan desa dan kader kesehatan. Mereka berasal dari berbagai usia, pendidikan, pekerjaan, dan jumlah anak. Karakteristik khalayak sasarn dapat dilihat pada tabel 1.

Tabel 1. Karakteristik Khalayak Sasaran

\begin{tabular}{lcc}
\hline Karakteristik Responden & N & $\%$ \\
\hline Usia & 4 & 13 \\
$16-20$ tahun & 11 & 37 \\
$21-25$ tahun & 15 & 50 \\
26-30 tahun & 0 & 0 \\
Pendidikan & 7 & 23.3 \\
SD & 19 & 63.3 \\
SMP & 4 & 13.4 \\
SMA & & \\
Sarjana & 19 & 63 \\
Pekerjaan & 9 & 30 \\
Swasta & 2 & 7 \\
IRT & 0 & 0 \\
Wiraswasta & & \\
PNS & 18 & 60 \\
Jumlah Anak & 12 & 40 \\
Anak 1 & & \\
2 orang anak & 19 & 63 \\
Tinggal serumah dengan & 5 & 17 \\
Keluarga inti & 6 & 20 \\
Orang tua & & \\
Mertua & 30 & 100 \\
Informasi yang pernah didapat & 0 & 0 \\
Pernah & & \\
Belum pernah & &
\end{tabular}


Tingkat pengetahuan dan sikap khalayak sasaran diukur menggunakan kuesioner tentang MP-ASI. Pengetahuan dan sikap ibu pada saat pre dan post test dapat dilihat pada tabel 2 dan 3.

Tabel 2. Distribusi pengetahuan Ibu sebelum dan sesudah pemberian pendidikan kesehatan di Posyandu Desa Hendrosari Menganti Gresik

\begin{tabular}{lcccc}
\hline \multirow{2}{*}{ Pengetahuan } & \multicolumn{2}{c}{$\begin{array}{c}\text { Sebelum Pendidikan } \\
\text { Kesehatan }\end{array}$} & \multicolumn{2}{c}{$\begin{array}{c}\text { Sesudah Pendidikan } \\
\text { Kesehatan }\end{array}$} \\
\cline { 2 - 5 } & $\mathrm{n}$ & $\%$ & $\mathrm{n}$ & $\%$ \\
\hline Baik & 21 & 70 & 30 & 100 \\
\hline Cukup & 8 & 27 & 0 & 0 \\
\hline Kurang & 1 & 3.3 & 0 & 100 \\
\hline Total & 30 & 100 & 30 & 0 \\
\hline
\end{tabular}

Tabel 3. Distribusi sikap Ibu sebelum dan sesudah pemberian pendidikan kesehatan di Posyandu Desa Hendrosari Menganti Gresik

\begin{tabular}{lcccc}
\hline \multirow{2}{*}{ Sikap } & \multicolumn{2}{c}{$\begin{array}{c}\text { Sebelum Pendidikan } \\
\text { Kesehatan }\end{array}$} & \multicolumn{2}{c}{$\begin{array}{c}\text { Sesudah Pendidikan } \\
\text { Kesehatan }\end{array}$} \\
\cline { 2 - 5 } & $\mathrm{n}$ & 57 & $\mathrm{n}$ & $\%$ \\
\hline Positif & 17 & 43.33 & 22 & 73.3 \\
\hline Negatif & 13 & 100 & 30 & 26 \\
\hline Total & 30 & & 300 \\
\hline
\end{tabular}

\section{Kesimpulan}

Kegiatan yang dilakukan mulai dari edukasi tentang MP-ASI, Peragaan penyiapan MP-ASI, dan Small Group Discussion (SGD) berjalan dengan baik dan $100 \%$ dalam kategori berhasil. Ditandai dengan meningkatnya pengetahuan ibu tentang MP-ASI yang dilakukan dengan menggunakan metode ceramah dan media leaflet diikuti dengan sikap ibu yang positif terhadap MP-ASI artinya ibu tidak memberikan MP-ASI ke bayi sebelum usia enam bulan. Ibu juga bisa mempraktekkan MP-ASI sesuai usia bayi dengan konsistensi yang benar. Kegiatan SGD ibu aktif bertanya dan diskusi tentang MP-ASI, ibu juga mengikuti semua kegiatan dari awal sampai akhir dengan semangat. Metode pemberian edukasi tentang MP-ASI, peragaan penyiapan MP-ASI dan SGD terbukti efektif untuk meningkatkan pengetahuan dan sikap ibu tentang MP-ASI. Diharapakn dengan adanya pendidikan kesehatan ini menjadi perbaikan dan perubahan pengetahuan dan sikap pada ibu untuk tidak memberikan MP-ASI pada bayi usia kurang dari 6 bulan.

\section{Ucapan Terima Kasih}

Terima kasih sebesar-besarnya disampaikan kepada Rektor dan Kepala Lembaga Penelitian dan Pengabdian Masyarakat Universitas Gresik yang telah memberikan dukungan dana untuk kegiatan ini. Selain itu, terima kasih pula disampaikan kepada Kepala Desa Hendrosari Menganti Gresik, Kader kesehatan, dan Bidan Desa yang telah mendukung dan memfasilitasi kegiatan pengabdian ini.

\section{Referensi}

Aryani, W. (2010). Aneka Menu Sehat Bayi . Yogyakarta: PT Gramedia.

Isni, K, \& Dhini, S.M. (2020). Pelatihan Pengukuran Status Gizi Balita sebagai Upaya Pencegahan Stunting Sejak Dini pada Ibu di Dusun Randugunting, 
Sleman, DIY. Jurnal Panrita Abdi, 4(1), 60-68.

Kudsiah, H., Rahim, S.W., Rifa’, M.A., \& Arwan. (2018). Demplot Pengembangan Budidaya Kepiting Cangkang Lunak di Desa Salemba, Kecamatan Ujung Loi, Kabupaten Bulukumba Sulawesi Selatan. Jurnal Panrita Abdi, 2(2), 151-164.

Krisnatutu, Y. (2008). Pedoman Umum Pemberian Makanan Pendamping Air Susu Ibu (MP-ASI). Jakarta: Derektorat Jendral Bina Kesehatan Masyarakat.

Marimbi, H. (2010). Tumbuh Kembang, Status Gizi \& Imunisasi Dasar pada Balita. Yogyakarta : Nuha Medika.

Nadesul, H. (2011). Makanan Sehat Untuk Bayi. Jakarta: Puspa Swara.

Notoatmodjo, S. (2007). Pendidikan dan perilaku Kesehatan Masyarakat, Dalam: Kesehatan Masyarakat Ilmu dan Seni. Jakarta: PT Rineka Cipta.

Tirtawinata, C. (2006). Makanan dalam Perspektif Al-Quran dan Ilmu Gizi. Jakarta: Pustaka Bunda.

WHO. (2006). Infant and Young Child Feeding Counselling: An Integrated Course.

Widyastuti, D. (2011). Panduan Perkembangan Anak 0-1 Tahun. Jakarta: Puspa Swara.

Yenrina. (2008). Menyiapkan Makanan Pendamping. Jakarta: Puspa Swara

Penulis:

Yuanita Syaiful, Program Studi Ilmu Keperawatan Fakultas Ilmu Kesehatan Universitas Gresik, Email: ntsyaiful271@gmail.com

Lilis Fatmawati, Program Studi Ilmu Keperawatan Fakultas Ilmu Kesehatan Universitas Gresik, Email: lilisfatmawati13@gmail.com

Siti Aminah, Mahasiswa PSIK FIK Universitas Gresik. Email: wf_ab@yahoo.co.id

Bagaimana men-sitasi artikel ini:

Syaiful, Y., Fatmawati, L., \& Aminah, S. (2020). Peningkatan Pengetahuan dan Sikap Ibu tentang

Makanan Pendamping Air Susu Ibu (MP-ASI) di Desa Hendrosari Menganti Gresik. Jurnal Panrita Abdi, (4)2, $195-204$. 